\title{
Defined Contingent On Relationship Completion Required Before Starting Indicator
}

National Cancer Institute

\section{Source}

National Cancer Institute. Defined Contingent On Relationship Completion Required

Before Starting Indicator. NCI Thesaurus. Code C93762.

Specifies whether the targ et activity must have completed prior to starting the source activity. 